\title{
Depopulation and rural shrinkage in Subantarctic Biosphere Reserves: envisioning re-territorialization by young people
}

\author{
Pablo Mansilla-Quiñones, Susana Cortés-Morales \& Andrés Moreira-Muñoz
}

Keywords: landscape-scale conservation, re-territorialization, Patagonia, volunteering, MAB Programme, rural depopulation, biosphere reserves

\section{Abstract}

Landscape-scale conservation at the regional level is an important challenge for Biosphere Reserves (BRs), especially those located in areas suffering from depopulation and rural shrinkage. This is the case of the BRs of the southernmost part of Chile, in the Magallanes region. An analysis of the implications of deterritorialization (the radical reduction or disappearance of inhabitants, their traditional ecological practices, and their material and affective links with the territory) is lacking in the literature, particularly in relation to the migration of young people towards other human settlements. This is a critical situation for BRs because there is a tight link between depopulation and the sustainability of socio-ecological systems. Here we discuss, on the one hand, the limitations and negative impacts of repopulation attempts by extractive industries and, on the other, the possibilities of involving rural youth in initiatives that encourage the re-territorialization of ecological practices and knowledge that have been developed by generations of local inhabitants, as a way of promoting bioculturally sustainable modes of re-inhabiting these territories.
Profile

Protected area

Torres del Paine and

Cabo de Hornos BRs

Mountain range

Magallanes and

Cordillera Darwin,

Chile

\section{Introduction}

For the last fifty years, Biosphere Reserves (BRs) have aimed to promote the sustainable development of areas with high social and ecological value, bridging the gap between the areas' inhabitants and nature. In doing so, models of socio-ecological interaction have been generated around BRs, so that global-scale challenges for sustainable development can be addressed at a local scale. Despite significant progress in this regard, assessing the difficulties and conflicts currently faced by the management of BRs in Chile (MoreiraMuñoz et al. 2019) reveals considerable challenges in the path towards a balanced relationship between humanity and the environment - a relationship that allows for alternative possible futures to be formulated at a time when the Anthropocene is leaving increasingly strong imprints on BRs.

Some of the most commonly found socio-environmental problems and conflicts in BRs relate to climate change, long-term droughts or devastating wildfires. In the context of human settlements, these are usually related to the impacts of accelerated urban growth, with their blurry and fragmented character affecting BRs' buffer and transitions zones (Moreira-Muñoz et al. 2019). However, one issue that has generally been overlooked in relation to BRs is the geographically specific consequences of global processes of depopulation and rural shrinkage (Feldhoff 2013; Abramsson \& Hagberg 2018; Alata et al. 2018; Hill \& Nel 2018). An analysis of the implications of deterritorialization (the radical reduction or disappearance of the inhabitants, their traditional ecological practices, and their ma- terial and affective links with the territory) is missing, particularly in relation to the migration of young people towards urban areas, a movement which is closely linked to issues of overcrowding in towns and cities (Hasbaert 2012; Rey Benayas et al. 2007).

The question that leads our reflection is: what happens to human-environment relationships promoted by BRs that face accelerated rural depopulation? And in relation to this, how do the processes of rural depopulation challenge the biocultural sustainability of BRs, and how can these challenges be addressed in collaboration with local young people, acknowledging them as key actors? These questions are especially relevant in the uncertain political and economic contexts produced at a global scale as the result of globalization, climate change and pandemics. Under these circumstances, it is to be expected that many human settlements might experience socio-spatial reduction and depopulation. Rural shrinkage refers to "[a] wider concept than population decline [...] incorporating not only demographics but also drivers, outcomes and impacts of the process as well as governance, planning and policy response aspects" (Pužulis $\&$ Küle 2016). Therefore, studying the implications of depopulation and rural shrinkage is essential for thinking about current and future challenges regarding the sustainable development of BRs.

González and Vega (2016), in the context of Spain, illustrate the urgency of discussing the problems generated by depopulation in relation to BRs. In Cantabria, the processes of depopulation have been one of the main dynamics faced by management and development plans for rural settlements and BRs. This is critical for BRs because, as suggested by Segundo Métay et 


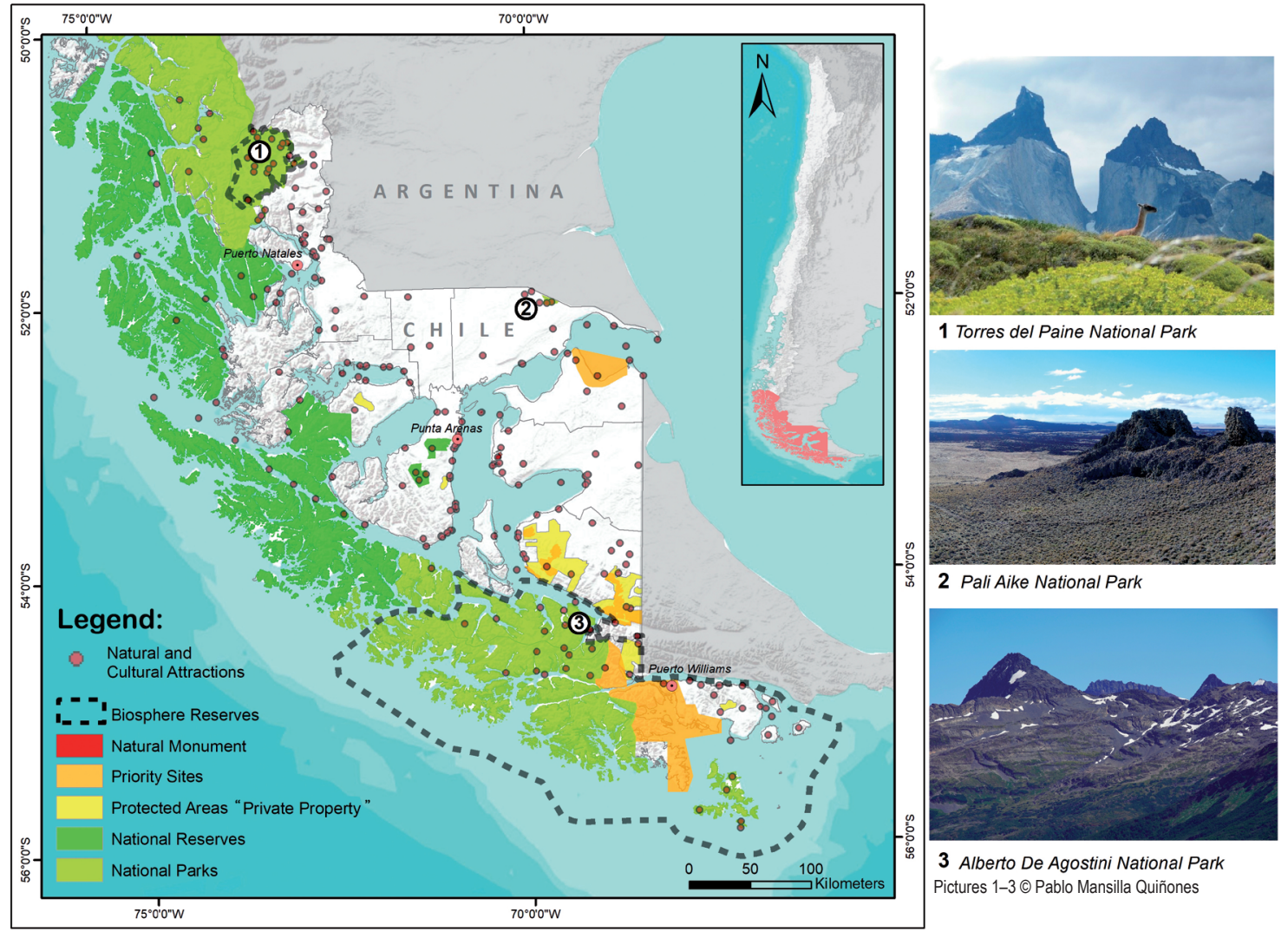

Figure 1 - Conservation areas and landscapes of Magallanes region in southernmost Chile: protected areas and two Biosphere Reserves (Torres del Paine and Cabo de Hornos). Database: Infraestructura de Datos Geoespaciales de Chile, IDE Chile. Design: Pablo Mansilla-Quinones

al. (2012), there is a very close link between depopulation and the sustainability of socio-ecological systems: when depopulation occurs, the networks established between human societies and nature are disrupted, and socio-ecological systems disintegrate, for example through the conversion of farmlands into industrialized agriculture, reducing biodiversity and agrodiversity (Segundo Métay et al. 2012), which in turn further reinforces depopulation processes, in a cyclical fashion. An interesting assumption in this regard is that rural depopulation may be beneficial for the recovery of biodiversity in BRs, the assumption being that wildlife will recolonize the ruins of abandoned human settlements. However, depopulation does not guarantee richer biodiversity. On the contrary, it may imply new problems such as invasive species or plagues affecting native wildlife, species traditionally controlled by human agricultural-ecological practices that have a symbiotic character. For example, from an ethnobotanical perspective, Pardo de Santayana and Gómez Pellón (2003) point out that rural depopulation implies the loss of knowledge and cultural practices associated with the use of plants by the local inhabitants, passed down from generation to generation. Human depopulation has a more-than-human impact, and conservation efforts must find ways to "reverse depopulation and support local (traditional) income sources and land uses" (Ibisch et al. 2010, p. 93).

\section{BRs in the Chilean Magallanes Region}

BRs are a network of conservation areas integrated at inter- and intra-regional scale, having the potential to constitute sustainable landscapes (Rodríguez-Rodríguez 2012; Romano et al. 2020). They are key for landscape-scale conservation planning (Trombulak \& Baldwin 2010). The Southern extremity of Chile, encompassing the Magallanes Region and the Chilean Subantarctic area, harbours two BRs: Torres del Paine and Cabo de Hornos. The regional conservation landscape also comprises a series of other conservation sites (Figure 1).

Torres del Paine was one of the first BRs to be declared in Chile (1978), and is one of the most visited protected areas in the country (more than 300000 visitors a year). The challenges for its appropriate management relate to its carrying capacity for tourism, wildfire control, and conflicts with cattle-raising practices (CONAF 2020). Cabo de Hornos encompasses almost five million hectares, including land and sea, with a broad diversity of landscapes, terrestrial, freshwater and marine ecosystems in the Subantarctic region, the Darwin mountain range, and the city of Puerto Williams $^{1}$ at the southern tip of the continent. Among the most significant aspects of this BR is its association

Puerto Williams: population 1868 in 2017 (INE 2019) 

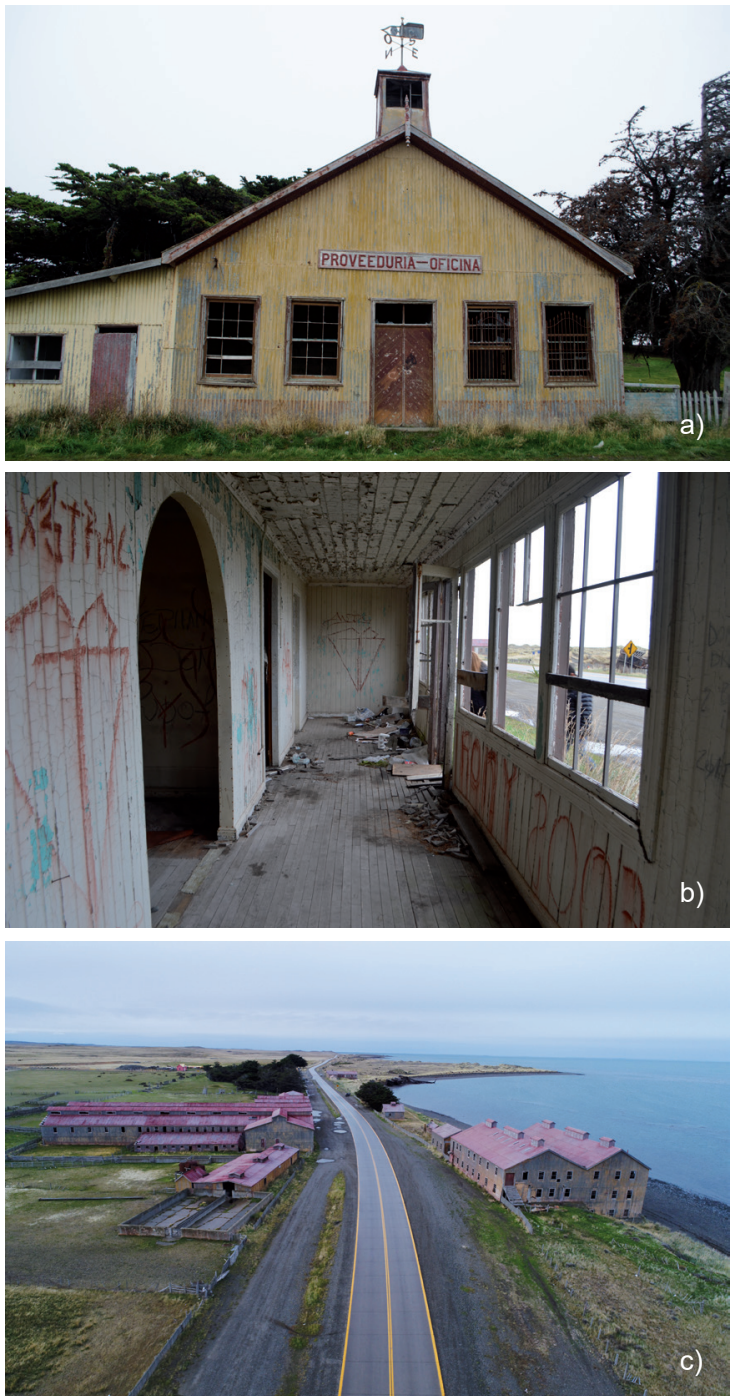

Figure 2 - The old (abandoned) San Gregorio Estancia, currently being promoted as a future tourist project. a) Old warehouse that supplied food and other goods to the workers; b) Interior of abandoned house; c) General aerial view of the Estancia San Gregorio. (C) Pablo Mansilla Quiñones

with the last descendants of the Yagán people (Anderson 2014). The BR includes sites of biocultural value such as Omora Ethnobotanical Park (Rozzi \& Schüttler 2015), and has been extended to cover the Diego Ramírez Islands and Drake Passage Marine Park (Rozzi et al. 2017). These protected areas together constitute a complex network of research sites (Red LTSER Cabo de Hornos; Rozzi et al. in press).

The territoriality of ancestral peoples such as the Haush, Aonikenk, Selknam, Yagán and Kawésqar converge in these ecosystems - even if, often, the evidence for them is in the form of very subtle marks left on the landscape. These peoples have historically inhabited these wild territories, where life is made possible thanks to deep ethnobotanical knowledge. These traditional lands have a strong bio-geocultural base that combines geologically interesting landscapes and conservation landscapes (Manríquez et al. 2019).
Extermination and failed repopulation by extractivist activities in the BRs

The first traces of depopulation in these territories bear the marks of the extermination of the indigenous populations during the colonial period, when Patagonia was socio-spatially shaped by internal colonialism promoted by the Chilean state through the auction of lands. This enabled a system of large estates (estancias) and sheep farming (Figure 2), which replicated the English model. Indigenous people were seen as an enemy, as they hunted sheep. Their extermination was dramatic, with landowners even paying a bounty for the ears of indigenous people, promoting hunting of human beings. In this colonial relationship, nature and its inhabitants were seen as objects of colonization, and sustainability was seen only from an economic perspective (Martinic 2006). This same logic still exists today, embodied by large Patagonian estates that adjoin BRs, where the power and interests of landowners clash with the interests of conservation, generating conflicts (Meynard 2014).

A second process that shapes the history of population and depopulation in the Magallanes region is the exploitation of oil in the $20^{\text {th }}$ century. Even though oil exploitation promoted the development of rural settlements and population increase, workers were mobile, hindering territorial rooting processes. They were also mainly men, configuring a social geography from which women and children were almost absent. In addition, fracking generated subsoil pollution and industrial waste, with severe negative impacts. The area has also seen coal mining, for example the Mina Invierno project in Riesco Island (Milesi 2016). The mine's closure due to its highly negative environmental impact resulted in the mass lay-off of hundreds of workers who had increased the rural population of the area. There are also traces of logging, which accelerated deforestation and desertification.

Finally, one of the main extractivist dynamics in this area relates to salmon farming, an activity that has become increasingly present in the region, putting pressure on BRs and the traditional rural lives of inhabitants. The Yagán community of Bahía Mejillones opposed and prevented the installation of Norwegian salmon farming companies in the area, arguing that they would affect local ways of life, human and nonhuman, and the territorial and cultural rights of Yagán people (Mundo Acuicola 2019).

The touristic potential of the BRs has been equally unsuccessful in terms of encouraging repopulation, especially in relation to young people: the local tourism industry is highly elitist, oriented towards international high-income tourists, and operated mainly by big companies. At the same time, the intense tourist activity in the region, with thousands of annual visitors, has put significant pressure on ecosystems, notably by increasing the occurrence of forest fires, such as the catastrophic events that occurred in 2005 and 
2011 (Meynard 2014). Tourism activities of this kind are unable to retain inhabitants within these territories, while the activities that do retain (a certain) population within the area are of an extractivist character, with serious detrimental environmental impacts.

\section{Young people and repopulation in BRs}

In the context that we have described here, a key question emerges: how can we advance towards landscape-scale conservation where processes of rural depopulation are under way? We believe that it is essential to design strategies that involve younger generations who are living within the BRs, through innovative and creative actions that encourage ecological improvements and a sense of belonging to the land (see Figure 3). Most young people who are native to these areas migrate towards urban centres, disenchanted with rural life, mainly due to geographical isolation and the lack of educational, work and social opportunities. In this regard, we can take inspiration from initiatives designed to encourage young people to return to (or stay in) their traditional lands. Fuentes Acuña and Marchant (2016), for example, describe agro-ecological initiatives that seek to promote family and community-based collective actions (see Figure 3) and a sustainable relationship with nature through non-extractivist alternatives.

An important aspect to consider here is the promotion of educational models driven by sustainability as a way to motivate young people's territorial attachment (Sabaini \& Moreira-Muñoz 2014). It is particularly important to generate actions within networks of educational institutions in BRs, involving local students in BRs, for example through volunteering, as in BRs in Africa (Salu 2013) and Italy (Santi et al. 2019). It is also interesting to consider initiatives that seek to involve young people in new and traditional crafts, encouraging forms of working that are closely related to nature. An example of this is the basket-weaving or wickerwork developed by the Yagán and Kaweskar peoples. This craft involves using and managing peat bogs and native vegetation present in Subantarctic BRs. In a similar vein is the hand-crafting of harpoons and traditional navigation tools, such as those made by Martin Gonzalez, a traditional Yagán craftsman who died in 2020. These kinds of crafts require strategies for knowledge to be passed on from one generation to another in order to survive.

From a transdisciplinary perspective, we suggest the potential of Creative Geographies, which open up interesting possibilities for connecting arts, science and nature with the biocultural landscapes of Patagonia, enabling people to re-explore their life-places through their senses, and to re-learn how to observe their connections with place and nature (Tsing et al. 2017). Some remarkable experiences in this regard include activities developed by BRs in association with museums, such as the Rio Seco Natural History Mu-
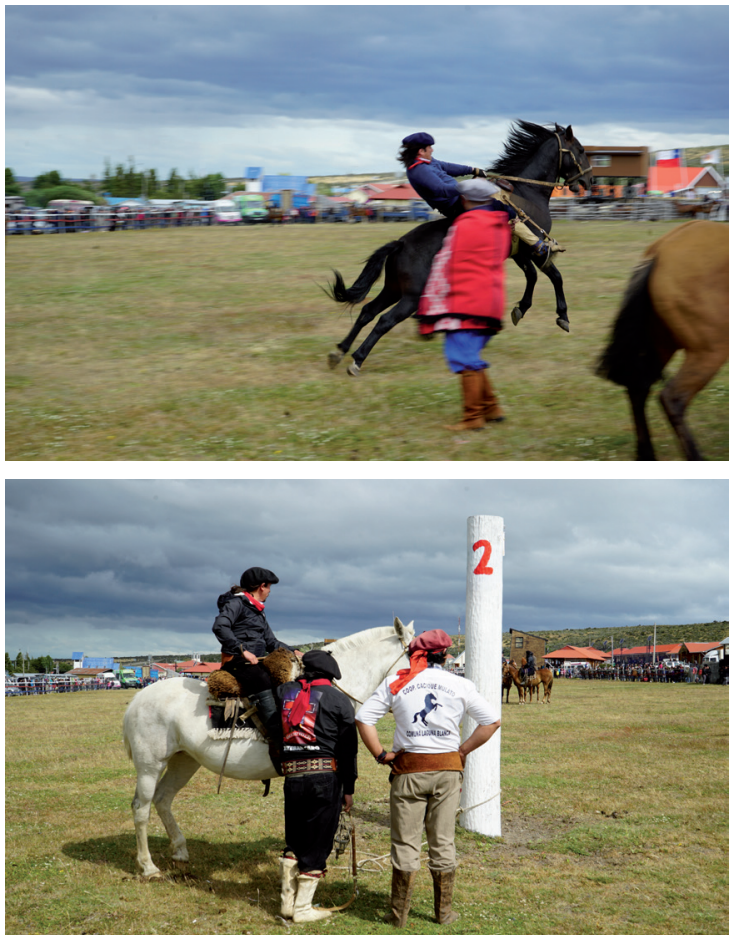

Figure 3 - Young inhabitants of rural areas in traditional activities: competitions in horsemanship. (C) Pablo Mansilla Quiñones

seum, which has a rich and varied collection of marine animals and where biological and artistic values are promoted; or Martín Gusinde Anthropological Museum in Cabo de Hornos BR, where the ecological and archaeological history that has shaped the area is narrated. Here, the inhabitants of the territory, especially the Yagan community, have been actively involved. Artistic activities have also been developed in Villa Dorotea, where the artist Álvaro Pavéz Cataldo led the creation of the Dorotea Popular Museum, involving the local community in recovering their memory of this place. There are also artistic-cultural groups such as Liquenlab, which works to promote the dialogue between the arts and science, questioning in a creative way their relationships with the environment in Patagonia.

It is key to bear in mind, however, that if we seek to generate profound changes, educational / artistic / scientific initiatives need to develop an understanding of humanity and nature that does not further deepen this ontological divide - an understanding of humanity as part of nature and its ecosystems, rather than as beings more or less connected to an external nature.

\section{Final reflections}

Accelerated depopulation in Magallanes (see Table 1) implies human demographic changes, but it may also have a profound impact on the ways in which all its denizens, human and non-human, inhabit a territory in interdependent ways. Depopulation brings in 
Table 1 - Demographic trends of young people and depopulation processes in the Magallanes region. Source: Census of Population and Housing in Chile, years 1992, 2002 and 2017 (INE 1992, 2002, 2017). *Young people: 18-24 years old.

\begin{tabular}{|c|c|c|c|c|c|}
\hline \multicolumn{2}{|c|}{ Scale } & \multirow{2}{*}{\begin{tabular}{|r|}
$\begin{array}{l}\text { Total young } \\
\text { population* }\end{array}$ \\
13260
\end{tabular}} & \multirow{2}{*}{\begin{tabular}{|r|}
$\begin{array}{l}\text { Total } \\
\text { population }\end{array}$ \\
131592 \\
\end{tabular}} & \multirow{2}{*}{$\begin{array}{r}\begin{array}{l}\text { Young } \\
\text { people (\%) }\end{array} \\
10.1 \\
\end{array}$} & \multirow{2}{*}{$\begin{array}{l}\begin{array}{l}\text { Relative intercensal } \\
\text { variation 1992-2017 }\end{array} \\
15.61\end{array}$} \\
\hline \multirow{10}{*}{$\frac{\frac{n}{U}}{\frac{\omega n}{\frac{n}{a}}}$} & Punta Arenas & & & & \\
\hline & Laguna Blanca & 16 & 274 & 5.8 & -35.68 \\
\hline & Rio Verde & 60 & 617 & 9.7 & 98.39 \\
\hline & San Gregorio & 38 & 799 & 4.8 & -36.13 \\
\hline & Cabo de Hornos & 176 & 2063 & 8.5 & 27.66 \\
\hline & Porvenir & 802 & 6801 & 11.8 & 35.64 \\
\hline & Primavera & 56 & 1158 & 4.8 & -21.70 \\
\hline & Timaukel & 37 & 405 & 9.1 & 61.35 \\
\hline & Puerto Natales & 1805 & 21477 & 8.4 & 25.19 \\
\hline & Torres del Paine & 179 & 1209 & 14.8 & 216.49 \\
\hline \multicolumn{2}{|c|}{ National } & 1897114 & 17574003 & 10.8 & 31.66 \\
\hline \multicolumn{2}{|c|}{ Regional } & 16431 & 166533 & 9.9 & 13.84 \\
\hline
\end{tabular}

its wake the loss of knowledge in relation to nature, of the social meanings attached to the ways of naming and narrating nature, of the ways of imagining and seeing the territory, and of collaborative and spatial practices (Mansilla Quiñones \& Melin Pehuen 2019). The close relationship between the dynamics of the human population and the exploitation of natural resources in the context of fragile ecosystems will result in time in human-nature relations becoming unsustainable. Public and private institutions seek to increase populations while exploiting and endangering natural resources, promoting extractivist economies. However, this extractivist model does not succeed in keeping people in their traditional lands, such that depopulation becomes an imminent dynamic. As argued by Güler and Kâhya (2019, p. 98), "many of these abandoned rural settlements have invaluable vernacular assets that bear the traces of past rural life and comprise the spirit of these cultural landscape areas".

Young people need to be included in rural contexts (Trivelli \& Morel 2020), and within BRs. This implies generating actions to promote the re-territorialization (Price 2017) of centuries-old ecological practices and traditional forms of local knowledge, including how to read bio-geocultural landscapes and valuing them (Price 2017). It also requires paying attention to the new and original ways of learning and of relating to their territories that young people have adopted (Muñoz et al. 2006; Barraclough et al. 2020). This is particularly relevant in territories such as the Cabo de Hornos and Torres del Paine BRs, where modes of inhabiting Patagonia are rooted deeply in fragile and political perceptions of nature.

\section{Acknowledgements}

The research presented here was made possible thanks to financial support from: ANID FONDECYT $\mathrm{N}^{\circ}$ 11181086, Uninhabiting the Extremes: Transformations in Rural Living in Magallanes; Anillos 180040 PIAANID GeoHumanities and Creative (Bio)geographies approaching sustainability; and the Millennium Scientific
Initiative Programme - Millennium Nucleus Mobility and Territories - MOVYT, NCS17_027.T.

\section{References}

Abramsson, M. \& J.-E. Hagberg 2018. What about community sustainability? - Dilemmas of ageing in shrinking semi-rural areas in Sweden. Scottish Geographical Journal 134(3-4): 103-121.

Alata, E., B. Fuentealba \& J. Recharte 2018. El despoblamiento de la puna: efectos del cambio climático y otros factores. Revista Kawsaypacha: Sociedad y Medio Ambiente 2: 49-69. Doi: 10.18800/ kawsaypacha.201801.003

Anderson, C.B. 2014. Lecciones sobre la creación e implementación de la RB Cabo de Hornos como plataforma de investigación de largo plazo. In: Moreira-Muñoz, A. \& A. Borsdorf (eds.), Reservas de la Biosfera de Chile: Laboratorios para la Sustentabilidad. Serie Geolibros 17: 230-249.

Barraclough, A.D, L. Schultz \& I.E. Måren 2021. Voices of young biosphere stewards on the strengths, weaknesses, and ways forward for 74 UNESCO Biosphere Reserves across 83 countries. Global Environmental Change 68: 102273.

CONAF (Magallanes y de la Antártica Chilena) 2020. Reserva de Biosfera Torres del Paine: Desafios de un nuevo territorio. www.parquetorresdelpaine.cl

Feldhoff, T. 2013. Shrinking communities in Japan: Community ownership of assets as a development potential for rural Japan? Urban Design International 18(1): 99-109. Doi: 10.1057/udi.2012.26

Fuentes Acuña, N.R \& C. Marchant 2016. ¿Contribuyen las prácticas agroecológicas a la sustentabilidad en la Agricultura Familiar de Montaña? El caso de Curarrehue, región de la Araucanía, Chile. Cuadernos de Desarrollo Rural 13(78): 35-66.

González, J.S. \& J.R. Vega 2016. Gestión, protección y despoblación en las Reservas de la Biosfera de la Cordillera Cantábrica. Pirineos 171: e025.

Güler, K. \& Y. Kâhya 2019. Developing an approach for conservation of abandoned rural settle- 
ments in Turkey. A|Z ITU Journal of Faculty of Architecture 16(1): 97-115.

Haesbaert, R. 2012. El mito de la desterritorialización: del fin de los territorios a la multiterritorialidad. México: Siglo Veintiuno.

Hill, T. \& E. Nel 2018. Population change in the Karoo. African Journal of Range \& Forage Science 35: 203-208. Doi: 10.2989/10220119.2018.1529705

Ibisch, P.L., A. Vega E. \& T.M. Herrmann (eds.) 2010. Interdependence of biodiversity and development under global change. CBC Technical Series No. 54. Secretariat of the Convention on Biological Diversity, Montreal (second corrected edition).

INE 1992. Censo de Población y Vivienda 1997. Chile: Instituto Nacional de Estadística.

INE 2002. Censo de Población y Vivienda 1997. Chile: Instituto Nacional de Estadística.

INE 2017. Censo de Población y Vivienda 1997. Chile: Instituto Nacional de Estadística.

INE 2019. INE oficializa a Puerto Williams como "ciudad" y se convierte en la "ciudad más austral del mundo". Available at: http://www.gobernacionantartica.gov. $\mathrm{cl} /$ noticias/ine-oficializa-a-puerto-williams-comociudad-y-se-convierte-en-la-ciudad-mas-austral-delmundo/ (accessed: 21/07/2021)

Manríquez, H., P. Mansilla Quiñones, R. FigueroaSterquel \&. A. Moreira-Muñoz 2019. Geodiversity meets Biodiversity: a landscape approach for biogeocultural conservation and governance in Mediterranean central Chile. eco.mont - Journal on protected mountain areas research and management 11(1): 43-48

Mansilla-Quiñones, P. \& M. Melin Pehuen 2019. A Struggle for Territory, a Struggle Against Borders. NACLA Report on the Americas 51(1): 41-48.

Martinic, M. 2006. El poblamiento rural en Magallanes durante el siglo XX: Realidad y utopía. Magallania (Punta. Arenas) 34: 5-20.

Meynard, M.F. 2014 Reserva de la Biosfera Torres del Paine: ¿cómo conciliar la conservación de la biodiversidad, el desarrollo turístico y el mantenimiento de la identidad ganadera? In: A Moreira-Muñoz \& A. Borsdorf (eds.), Reservas de la Biosfera de Chile: Laboratorios para la Sustentabilidad. Serie Geolibros 17: 230-249.

Milesi, O. 2016 Coal Mine Threatens Ecological Paradise in Chile's Patagonia Region. Available at: http:// www.ipsnews.net/2016/11/coal-mine-threatensecological-paradise-in-chiles-patagonia-region / (accessed: 21/07/2021)

Moreira-Muñoz, A., F. Carvajal-Mascaró, S. Elórtegui \& R. Rozzi 2019. The Chilean Biosphere reserves network as a model for sustainability? Challenges towards regenerative development, education, biocultural ethic an eco-social peace. In: Reed, M.G. \& M.F. Price (eds.), Unesco Biosphere Reserves supporting biocultural diversity sustainability and society: 61-75.

Mundo Acuicola 2019. Se manifiestan contra instalación de salmoneras en canal Beagle durante visita de reyes noruegos a Magallanes. Available at: https://www.mundoacuicola. $\mathrm{cl} / \mathrm{new} / \mathrm{se}-\mathrm{manifiestan}$-contra-instalacion-de- salmoneras-en-canal-beagle-durante-visita-de-reyesnoruegos-a-magallanes/ (accessed 24/08/2021)

Muñoz, M.D., L. Pérez, R. Sanhueza, R. Urrutia \& A. Rovira 2006. Los paisajes del agua en la cuenca del río Baker: bases conceptuales para su valoración integral. Revista de Geografía Norte Grande 36: 31-48.

Pardo de Santayana, M. \& E. Gómez Pellón 2003. Etnobotánica: aprovechamiento tradicional de plantas y patrimonio cultural. Anales del Jardín Botánico de $M a$ drid: 60(1): 171-182. Available at: http://hdl.handle. net/10261/2488 (accessed: 13/07/2021)

Price, M.F. 2017. The re-territorialisation of Biosphere Reserves: The case of Wester Ross, Northwest Scotland. Environmental Science Policy 72: 30-40.

Pužulis, A. \& L. Kūle 2016. Shrinking of Rural Territories in Latvia. European Integration Studies 10: 90-105. Doi: 10.5755/j01.eis.0.10.14988

Rey Benayas, J.M., A. Martins, J.M. Nicolau \& J.J. Schulz 2007. Abandonment of agricultural land: an overview of drivers and consequences. $C A B$ Reviews 2(57): 1-14.

Rodríguez-Rodríguez, D. 2012. Integrated networks. A territorial planning proposal for biodiversity conservation in urban, densely populated regions. The case of the Autonomous Region of Madrid, Spain. Journal of Environmental Planning and Management 55(5): 667-683.

Romano, J., E. Pérz-Chinarro \& B.V. Coral 2020. Network of Landscapes in the Sustainable Management of Transboundary Biosphere Reserves. Land 9: $1-24$.

Rozzi, R. \& E. Schüttler 2015. Primera década de investigación y educación en la Reserva de la Biosfera Cabo de Hornos: El enfoque biocultural del Parque Etnobotánico Omora. Anales Instituto Patagonia (Chile) 43(2): 19-43.

Rozzi, R., R.D. Crego, T. Contador, E. Schüttler, S. Rosenfeld et al. (forthcoming). Extensión de la Red de Estudios Socio-Ecológicos A Largo Plazo (LTSERChile) en la Reserva de la Biosfera Cabo De Hornos y el nuevo Parque Marino Islas Diego Ramírez-Paso Drake. Magallania (In press).

Rozzi, R., F. Massardo, A. Mansilla, F.A. Squeo, E. Barros et al. 2017. Parque Marino Cabo de Hornos-Diego Ramirez: Technical report. Punta Arenas, Chile.

Sabaini, C. \& A. Moreira-Muñoz 2014. Educación para la Sustentabilidad: las Reservas de la Biosfera como espacios de reconexión con la Vida. In: MoreiraMuñoz, A. \& A. Borsdorf (eds.), Reservas de la Biosfera de Chile: Laboratorios para la Sustentabilidad. Serie Geolibros 17: 294-311

Salu, E. 2013. Protecting Bia Biosphere Reserve for Improved Biodiversity Conservation in Ghana. In: Pool-Stanvliet, R. \& M. Clüsener-Godt (eds.), AfriMAB: Biosphere Reserves in Sub-Saharan Africa: Showcasing Sustainable Development. Pretoria, South Africa: 73-89.

Santi, S., P. Cigalotto \& A. Benzoni 2019. The Italian Julian Alps - A new Biosphere Reserve for a sus- 
tainable future. eco.mont - Journal on protected mountain areas research and management 12: 46-51.

Santos González, J. \& J.M. Redondo Vega 2016. Gestión, protección y despoblación en las Reservas de la Biosfera de la Cordillera Cantábrica. Pirineos 171: 1-14.

Segundo Métay, I.G., G. Bocco Verdinelli \& P.S. Urquijo Torres 2012. Despoblamiento Rural y Geografía Ambiental: Consideraciones desde lo local. In: Fernández Christlieb, F. \& P. Urquijo Torres (eds.), Corografía y Escala Local: Enfoques desde la geografía cultural: 83-96.

Trombulak, S.C. \& R.F. Baldwin 2010. Introduction: Creating a Context for Landscape-Scale Conservation Planning. Landscape-Scale Conservation Planning 1-15. Doi: 10.1007/978-90-481-9575-6_1

Trivelli, C. \& J. Morel 2020. Rural Youth Inclusion, Empowerment, and Participation. The Journal of Development Studies: 1-15. Doi: 10.1080/00220388.2020.1808194.

Tsing, A., H. Swanson, E. Gan \& N. Bubandt (eds.) 2017. Arts of Living on a Damaged Planet. Minneapolis, London.

\section{Authors}

\section{Pablo Mansilla-Quiñones ${ }^{1}$}

Associate Professor in Human Geography, with a special interest in social geography and territorial studies. E-mail: pablo.mansilla@pucv.cl

\section{Susana Cortés-Morales}

Postdoctoral Researcher BIOGEOART Anillos SOC 180040. Special interest in childhood studies from a Common Worlds perspective.

Andrés Moreira-Muñoz ${ }^{1}$

Full Professor in Biogeography and Sustainable Geosystems, working on projects in the biodiversity of the natural heritage. E-mail: andres.moreira@pucv. $\mathrm{cl}$

1 Instituto de Geografía, Facultad de Ciencias de Mar y Geografía Pontificia Universidad Católica de Valparaíso, Valparaíso, Chile 